\title{
KHITAN STUDIES \\ I. THE GRAPHS OF THE KHITAN SMALL SCRIPT
}

\section{GENERAL REMARKS, DOTTED GRAPHS, NUMERALS}

\author{
ANDRÁS RÓNA-TAS \\ Department of Altaic Studies, University of Szeged \\ H-6722 Szeged, Egyetem u 2, Hungary \\ e-mail: aronatas3@t-online.hu
}

To the memory of Chinggeltei bagshi

\begin{abstract}
In the first part of this series of papers the author investigates the peculiarities and structure of the graphs of the Khitan Small Script. The graphs are polyvalent, and their phonetic values are based on and reflect the understanding of the Chinese phonetic system of the period. The list of graphs includes allographs and variants, further graphs with the same phonetic value but having different form(s). Some graphs have dotted and nondotted pairs. The Romanisation of the graphs is a convention by modern Chinese and European scholars. In some cases the phonetic value of a given graph is unknown, but its meaning is known; these are called logographs. Dotted forms and the numeric system are also investigated.
\end{abstract}

Key words: Khitan language, Khitan Small Script, graph, logogram, Old Mongolian, Proto Mongolian, Mongolic numeric system, gender in Khitan.

\section{Introduction $^{1}$}

The state-of-the-art of Khitan studies has been recently summarised by Chinggeltei (2002a, b), Kane (2009), Wu - Janhunen (2010), Janhunen (2012) and others. The broad

${ }^{1}$ This work has been carried out within the framework of the Turkological Research Group of the Hungarian Academy of Sciences and the University of Szeged. I owe special thanks to Professor Juha Janhunen for his help. The paper is the first part of a longer one. This paper was posted on Academia.edu. More than seventy scholars participated in the session. I am especially indebted to the following colleagues for their remarks: A. B. Apatóczky, B. Brosig, P. Golden, I. Gruntov, A. Hölzl, V. Ponaryadov, P. Rykin, A. Vovin and V. Zaytsev. I offer my sincere thanks to the anonymous reviewers of this paper. 
outlines of the scripts and the language of the Khitans are by now clear, so we can enter a new phase. This includes minute work on the details and structure of the script and the language. The following work is based on the achievements of former research and the Khitan material published mainly by Chinggeltei (2002a, b), Kane (2009) and $\mathrm{Wu}-$ Janhunen (2010).

\section{General Remarks}

The graphs ${ }^{2}$ of the Khitan Small Script may represent one phonetic unit or a section of phonetic sequences. For the Khitan scribe, a graph had one or more readings, and he was not aware of its phonemic structure and value. The Romanisation of a graph realises our concept of the reading. We know of graphs representing one, two, three and exceptionally four phonetic units. The situation is complicated by the fact that a graph may have more than one phonetic value or reading. For instance the graph (311) 丹 $<$ b $>$ may represent $/ \mathrm{b} /, / \mathrm{bV} /$ and $/ \mathrm{VbV} /$ :

bas(a) 丹冬 (311.174) <b.as> 'again' (K32, 72, 84, D6-5, 19-18, 21-6 33-6, $35-18,40-18, X 11-10,27-12,32-38,33-10,37-26,44-18)^{3}$. 冬 (174) may here denote [as] or [asa] | Mo basa, Da base, HN basa, DaE bas 'again, also'.

baka 丹カ $(311.168)<$ ba.qa>'son', pl. 丹列出 (311.151.290)<ba.hu.án> 'sons' (K72, 118, D13-11, 15-20, 26-7, 26-16, 16-24, X 8-4, passim) | Mo baga 'young, childhood', bagačud 'youth', Da bage 'little, young', bage.cude 'youth, young men', HN baga 'small', DaE --, DaTC bakš 'malyj, malenkij' || The vowel after $\langle\mathrm{b}\rangle$ may be either [a] or [o], the word was earlier read as boqo, Chinggeltei read baya, Aisin Gioro (2012) read the second graph $<\mathrm{qa}>$. The second syllable appears in ńoqa 伏力 $(222.168)<$ ń.qa $>$ 'dog', Liao shi niehe 捏褐 and in teqa'a 今 カ 为 $(247.168 .189)<$ te.qa.a> 'chicken', its reading as [qo] is here less probable. ${ }^{5}$

Abogiń 母 凡伏 $(311.334 .222)<$ b.g.ń> ‘a name, *Abogin' (X 4-29/31) | in Ch Abaojin 阿保謹 [?a-puaw-kin].

${ }^{2}$ The English terminology of Khitan studies is only in statu nascendi. I use Khitan as the name of the people and not Kitan, graph for the smallest units of the KSS and not sign or character, Khitan Small Script and not Kitan Assembled Script.

${ }^{3}$ The Khitan data beginning with a Khitan word in bold face are from my unpublished Khitan-English etymological word list. The "reading" is followed by the Khitan graph(s). In parentheses ( ) are the current number(s) in the List, in cone brackets $<>$ the Romanisation of the graph, between simple quotatation marks " ' stands the meaning in English, in parentheses ( ) the sigla and place of the sources where the word occurs, which is followed by remarks on the reading. After $\mid$ follow the Mongolian data, after $\|$ the discussion if necessary.

${ }^{4}$ I cite only the most relevant comparative Mongolian data; the literary Mongolian form from Lessing (1960) (L), a reconstructed form and the relevant data from the archaic Mongolian languages after Hans Nugteren (HN), Dagur after Martin (1961) (Da), Tumurdej-Cybenov (2014) DaTC, and after Enkhbat (1984) (DaE); the latter mostly from HN, but if necessary from the original.

${ }^{5}$ For the value [ba] of 母 see also bara'ān 丹本斗夹 (311.392.335/189.011), 丹本斗/为夹 $<$ ba.ra.ia.án>, <ba.ra.a.án> 'right side' $(K 72,114) \mid$ Mo baragun 'right-hand side, west', Da baren, $\mathrm{HN}$ baraun 'right (hand, side)', DaE bar'. 
This type of multiple reading has been mentioned earlier by Toyoda, Aisin Gioro and Kane (32). There can be no doubt about its existence, the question is: is this systematic or only a casual usage? We should not forget that the inventors and those who developed the KSS were not linguists. Their work was a practical one for practical purposes.

The readings of the graphs were in most cases ascertained by Chinese syllables which they used to transcribe. The correct reading of some graphs may have been helped by the fact that they are used in the same word in the same position as another graph already known. I quote such cases as $\mathrm{G}_{1} / \mathrm{G}_{2}$, that means graph1 and graph 2 have the same phonetic value in the same word.

The Romanisation, that is, the Latin letters used in the transcription of the graphs, was first adapted to the phonetic character of the Chinese texts transcribed by KSS. That means that the accepted transcription of KSS graphs is far from reflecting a phonetic reality, not to speak of phonemes. Nevertheless, as we shall see later, the system is very useful for reconstructing the Khitan phonemic system.

At the present moment we can put aside the phonetic peculiarities of the Khitan sound system - Khitan is a dead language, though we will come back to some of its features. It is more interesting to analyse the graphemic aspect of the question. In the first period of the deciphering of the KSS, all new graphs were put in a list with ascending numbers. If a new graph came up in a new text it got a new number. It can be predicted that as the volume of the corpus grows, the number of new graphs in each new text will decrease. Until the summer of 2000, 32 substantial texts were known and a few smaller ones, as bronze mirrors, a seal, inscriptions on various objects and coins (WJ25-29, SJL,Wikipedia). At present (2015) we know of 39 major inscriptions. The total number of preserved graphs may reach 100,000. In $2010 \mathrm{Wu}$ Yingzhe (Oyunchu) and Juha Janhunen published two newly found inscriptions, Nos 33 and 34. The Xiao Dilu (D, No 33) inscription is dated 1114, it was discovered in 2002 and acquired in May 2007, the Yelü Xiangwen inscription (X, No. 34) was dated 1091 and acquired in June 2007. The two inscriptions contain 78 graphs not listed before (Nos 381-459). Of these 78 graphs about 20 are identical with, or allographs of graphs in the earlier lists. That means that the two new inscriptions containing all 2700 graphs provided about 60 new items. This is a surprisingly high number, even if some of them turn out to be allographs of already known graphs.

There exist different lists, organised according to the stroke structure of KSS, such as that of Ji Ruhe and Wu Yingzhe (2009) and that of Sun Bojun, Jin Yongshi and Li Yang (2010). The first comprises 437, the second 448 graphs.

In the List we find 65 logographs, graphs of which we know the meaning, but not the pronunciation, such as 雨 (006) MOUNTAIN. Further there exist about 145 graphs of which we know neither the pronunciation nor their meaning. The high number of totally unknown graphs, which comprise almost $38 \%$ of the total number, is a great challenge.

The bottom line is that 173 graphs remain the pronunciation of which is given in several lists. As we shall see, even the reading of some of these graphs is uncertain. 
I will quote the list of WJ with a capital L: the List. On the other hand, these hundred and seventy odd graphs seem to be the most frequent ones.

On the whole we have to keep in mind that the pronunciation given by several scholars for a given graph is at the best an approximation or a hint to a possible pronunciation and closely bound to the Chinese syllables for which it was used. In other cases the Romanisation follows earlier conventions.

Kane gave a detailed description of the problems connected with the separate Khitan graphs (Kane 2009, pp. 26-30). Aisin Gioro, in her earlier papers and in her last one (2012) where she summarises her earlier findings, offers, in a few cases, different readings.

The script reflects a syllabic structure. We find the following structures of the graphs: V, C, CV, VC, CVC, VV, CVV, logographs and graphs of which we know neither the pronunciation nor the meaning.

Some Khitan syllables are represented by one graph, others by two or more similar graphs. It is very difficult to distinguish between two graphs which are written with a small difference, due to the hand of different scribes, or simple mistakes, or small but significant differences. In a few cases the rubbing, or photograph of the rubbing, is not very legible. For practical purposes we call them allographs, as in:

$$
\begin{array}{lll}
\text { ai } & <\mathrm{ai}>\text { ₹ }(122),<\mathrm{ai}_{3}> & \text { 平 }(395) \\
\text { bai }<\text { bai }>\text { 可 }(061),<\mathrm{bai}_{2}> & \text { 寸 }(060) \\
\text { em } & <\mathrm{em}>\text { 企 }(257),<\mathrm{em}_{2}> & \text { 企 }(256)
\end{array}
$$

In general such allographs are distinguished in the Romanisation by subscribed indexes.

In other cases the same Khitan syllabic unit is written with different graphs. In such cases the vowel of the transcription is noted with a diacritic, the form of which has no importance. We also find cases where allographs and different graphs existed for transcription of the same syllabic unit, as in:

$$
\begin{aligned}
& \text { au }<\mathrm{au}>\text { 丈 }(161),<\mathrm{au}>^{6} \text { 方 }(125),<\mathrm{aú}>\quad \text { 尔 }(210) \\
& \text { du }<\mathrm{du}>\text { 仃 (237), }<\text { dú }>\text { 飞 }(179),<\mathrm{du}>\text { 分 }(249) \text {, } \\
& \text { iu }<\mathrm{iu}>\text { 丙 }(019),<\mathrm{iu}>\text { 兯 (138), }<\mathrm{i} \overline{\mathrm{u}}_{2}>\text { 王 (382), <iú> 岀 (289), } \\
& \text { en }<\text { en }>\text { 杭 }(140) \text {, <én> 与 (361), <én }>\text { 与 (100), < <én }>\text { 与 (219), } \\
& <\text { én } 4>\text { 与 (399) }
\end{aligned}
$$

\section{Dotted and Nondotted Pairs of Graphs}

Kane mentions 12 pairs of graphs in the case of which one of the pairs is dotted, the other is not dotted. According to $\mathrm{Wu}-$ Janhunen (43) there exist 29 such pairs. Kane mentioned that this feature has been observed by several scholars. Wu (2005) suggested, that the dot indicates grammatical gender. Kane added, "the texts do not contradict that interpretation" (K27). This is true. The marking of gender in the case of

\footnotetext{
${ }^{6}$ I use $<\overline{\mathbf{0}}>$ instead of $<\hat{\mathrm{o}}>$ and $<\dot{\mathrm{n}}>$ instead of $<\tilde{\mathrm{n}}>$.
} 
numerals or other attributives is one of the most interesting features of the Khitan Small Script. The marked pair is always the male, the unmarked the female. Wu and Janhunen dealt with the dotted pairs on pp. $42-43$ of their work. If there exists a dotted form already deciphered and its nondotted pair is yet not deciphered, Wu and Janhunen use a raised small $x$, e.g. 古 $(047)<$ hor $>$, 古 $(046)<$ hor $^{\mathrm{x}}>$, while if the dotted is not yet deciphered, they use a small circle, as in: 乃 $(184)<\mathrm{am}>$, 乃 (185) $<\mathrm{am}^{\circ}>$. They also realised that the dot is not only used for gender specification.

Kane cited the following 12 pairs (K27)

004-005 承 WHITE 永 WHITE ${ }^{\circ}, 007-008$ 至 EIGHT 尘 EIGHT ${ }^{\circ}, 026-027$ モ ONE モ $\mathrm{ONE}^{\circ}, 029-030$ 戈 tau 过 tau (FIVE), 033-034 吞 is 忝 is ${ }^{\circ}$ (NINE), 081-082 女 MONTH 女 üe, 085-086 办 SIX 灰 SIX $^{\circ}, 134-135$ 圣 TWO 圣 $\mathrm{TWO}^{\circ}, 166-167$ 包 THREE 包 $\mathrm{THREE}^{\circ}, 265-286$ 山 GOLD 山 $\mathrm{GOLD}^{\circ}, 326-$ 327 文 $^{\mathrm{x}} \mathrm{e}^{\mathrm{x}}$ ie, 368-369 乇 FOUR モ FOUR ${ }^{\circ}$.

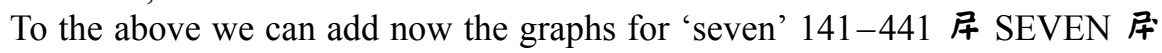
SEVEN ${ }^{\circ}$.

It is a bit more complicated with nine:

is $(033)<$ is $>$ 'nine, feminine'; the masculine form is $(034)(\mathrm{K} 24,109$, D49-9. 51-8, X4-21, 6-8, 28-10), <is $>$ (C107). On the reading, see below.

We have to suppose, that also in those cases where we did not find a "dotted pair" it can be found, in fact, in the case of adjectives, or nouns used as attributives? Let us see some functions which are not or not mainly connected with gender specification.

The first of the pair $<y>(020)$ 万 and $<m>(021)$ 万 is used when it occurs as an initial to represent [y] and [ye]. If it figures as a final, then it represents [ei]. It occurs i.a. in the clan name of the Khitan rulers, the Yelü. The second graph $<\mathrm{m}>(021)$ 万, is most probably not a dotted pair of (020). It is read as [mo] and identified, based on the glossary of the Liaoshi, as mo 'mother, female person'. In <mo.ba.qa> it has the meaning 'daughter', i.e. female child (ba.qa). Anyhow the dotted pair should be the male, and this is here surely not the case. A further dotted pair is $<\mathrm{ra}>$ 布 (084) and $<\mathrm{ra}>$ 本 (397). Both occur in the transcription of the same clan name:

Yarud 万布/布及灭 $(020.084 / 393.131 .344)<$ y.ra.u.ud > (D1-14) 'Yelü 耶律, clan name of the Khitan Emperors', LMCh jia lyt may give back a pronunciation like [yarüd] or [yärüd] $(\mathrm{K} 22,23,37: e i=\mathrm{Ch} y e, \mathrm{~K} 259)$. The origin and the variants of the clan name of the ruling Khitan clan were discussed by Wittfogel and Feng (WF59n). One of the other forms used was Yi-la 移剌. The LMCh reading of Yi 移 was Pjiaj. The first sign was written sometimes with $y i$ 亦 which was read in LMCh as jiajk. All these transcriptions suggest a Khitan syllable /yä/. The second syllable of the clan name 布/布 $(084 / 393)$ occurs also in word initial position: 布及 $(084.131 .273)$ $<$ ra.u.un $>$ 'a personal name or a part of it' (X39-3).

One has the impression that in these cases (084) has to be read /ar/ or /ara/ and the name has to be read Aruun. Perhaps it can be connected with Mo arigun

\footnotetext{
${ }^{7}$ I suppose that the dotting became general only in a later phase of the history of the KSS.
} 
'clean, pure, holy'. ${ }^{8}$ The graph 本 (397) has not yet been found in word initial position.

As we see, the correct Romanisation of 万布/布及灭 $(020.084 / 393.131 .344)$ is $<$ y.r.u.ud $>$. Taking into account the Chinese transcriptions, the name may have been slightly palatalised, and pronounced *Yärüd. ${ }^{9}$

Whether this clan name has anything to do with the name of the Jarud tribe in Inner Mongolia is a topic for further investigation.

The nondotted graph $<\breve{s}>(028)$ 叉 transcribes Chinese $/ \check{s} /$, and occurs in the Khitan word šen 考 $(028.073)<$ š.ēn $>$ 'new' $(K 38,188$, Sh2 $)<$ Sen $>(C 107) \mid$ Mo sine, Da šinken, HN sini, DahE šin-kən, šał-kan.

The pair graph has the dot above the graph $<\check{Z}>$ 文 (330). It is used only for transcription of Chinese / $\check{z} /$. In this case the dot is a diacritic.

In the case of $<$ hor $>$ 古 (046) and $<$ hor $>$ 古 (047) we have most probably another type. The Khitan word gor, also written $<$ hor.u $>$ 古及 $(046 / 047.131)^{10}$ has the meaning, according to Aisin Gioro (K40), 'people'. The initial is either a stop $/ \dot{\mathrm{g}} /$ or a fricative $/ \gamma /$.

Ġor 古 $(047)$, goru 古及 $(047.131)<$ hor.u>, also 古为 $(047.189)<$ hor.a $>$ 'people' (K57，111，202，X5-31)，古及必 (047.131.273) gen.<hor.u.un> (D28-13， 28-10, 43-18), plural (047.254) 古爸 < hor.d > (X29-12). The comparison with MMo haran pl. harad as suggested by Vovin (2013:624 $\leftarrow$ OT här, härä), can be excluded, the initial which became in Mo $h$ - > zero, was /p-/ in Khitan. The initial was either a guttural stop $/ \dot{\mathrm{g}} /$ or a fricative $/ \gamma /$. The word reminds one of Tibetan Hor 'Mongol', but the connection is not clear.

Whatever the Proto Mongol origin of the Khitan word gor/goru is, the dotted form marks male, and the nondotted form female members of the group of people. In this case it seems to occur with a noun.

Graph (100) <én $n_{2}>$ 与 has an allograph (361) 与 and an allograph (399) 占, and is mostly used as a marker of the genitive case in front vocalic words. The ordinal numbers (K143-144) quantifying feminine nouns have a suffix $<$ én $>$ 与. The ordinal numbers used with masculine nouns have among others the suffix $<$ er $>x$ (269), an allograph of which is (341) ㅅ․ㅅ. The opposition $<$ er $>:<$ en $>$ male:female *ere $: * e n e$ has to go back to nominal origins, and in this case *ene may have been a noun denoting a female being. We have to mention that er (341) 炎 is also used as the suffix of the past tense in front vocalic words.

Graph $(101)<\mathrm{deu}>$ 与 has a dot. Its meaning ‘younger brother' would fit into the pattern:

${ }^{8}$ I accept the arguments of P. Rykin and others expressed in the session of Academia.edu that the name of the Ilkhanid ruler Argun (1284-1294) may not pertain here.

${ }_{9}$ Jacques (2010) in his review on Kane (2009) mentioned that the name of the Khitans appear in Tangut transcription as $t 6 h j \hat{t}^{I} t \tilde{a}^{I}$ which also points to a strong palatalisation. The nasalised $/ \tilde{a} /$ is also interesting.

${ }^{10} \mathrm{Slash} /$ is used in cases where both graphs on the left and right side of the slash may appear on each other's place. 
dew 卉 $(101)<$ deu> 'younger brother' (K104, 119, X2-20, 3-14, 8-8, 9-2, 933, Sh2: $d$ ?w) | <ia deu> 'brothers', < du> (C107) | Mo degü, Da deü, HN deü, DaE dau 'younger sibling'. (101) has an allograph 古 (072) with the meaning 'EAST'. If (101) and (072) are only allographs, that is, they denote the same phonetic unit, then we have to suppose dew 'east'. Can we connect this word to Mo degedü 'higher, upper etc.' the root of which is *dege? But this is going back to *degü, see degüji- 'to be hung or suspended'. However if 'east' means the 'upper', 'west' should be the 'lower'. Mongolian and Chinese orientations face south; Turkic orientations face east. We have to put this into the system of the cardinal points, to which I will come back later.

Another question is that, if 5 (101) has a dot, does there exist a nondotted pair? Is this (453) 万 with a hitherto unknown pronounciation and meaning? The graph is said to be an allograph of 万 (129) with also no pronounciation or meaning. One would expect a word for 'younger sister'. In the Mo languages LM degü denotes both the male and the female younger siblings. If this is also here the case than (453) 万 has also the pronounciation dew and the meaning 'younger sister' while the graph (129) may be an allograph.

Graph 太 (118) <qú ${ }^{\mathrm{x}}>$ is a dotted graph, while 丈 $(117)<\mathrm{qu}>$ does not have a dot. Graph 余 (246) has the same pronunciation /qu/ and is alternatively used with (118) in the same word as in $<$ s.iau.qu $>$ 'blue'. In the corpus of WJ neither (118) nor (117) occur as initial syllables. One has the impression that (117) and (118) are suffixes, or are also used as suffixes marking female and male gender. The words $<$ m.as.qú $>$ 叉冬丈 (133. 174.118) and <m.as.qu $>$ 叉冬余 $(133.174 .246)$ have both the meaning 'first' (K48). In the Yelü Xiangwen inscription (line 10) $<$ m.as.qu $>$ 叉 冬 余 (133.174.246) is the attributive of $<$ ba.qa $>$ 'son'. This proves that (246) is an allograph of (118) and not of (117).

Graphs $<\mathrm{m}>$ 叉 (132) and $<\mathrm{m}>$ 叉 (133) are also pairs. Interestingly enough, (132) does not occur in word initial position, while (133), the dotted form, is frequent as a word initial. It occurs in the WJ corpus in more than 30 different words. It occurs also in word internal and final positions. It also appears in the word $<$ m. $\bar{o}_{2}$.qu $>$ 叉公 太 (133.253.118) 'first or eldest son, or the greatest son', that means that in this case two dotted graphs would signalise the male gender of the noun. Most probably the dot of the graph (133) lost its specific function.

The graphs 女 (172) and 条 (173) both <uh> are not occurring in word initial position. The transcription is conventional, it reflects an $u \gamma$ final in transcriptions of Chinese words, which had originally a final $-k$ as in Khitan $<1$.uh $>$ Chinese 祿 $l u<$ LMCh lawk (K55). On the use of $<\mathrm{h}>$ in Liao Chinese transcriptions, see K254.

The graphs $<\mathrm{ku}>\Omega(178)$ and $<\mathrm{ku}^{\circ}>$ 凡 (427) are also dotted pairs. The first has the meaning 'man'. This graph can hardly be separated from $<\mathrm{g}>\boldsymbol{\imath}$ (334). The difference is in voicing; "voiced" and "not voiced" readings alternate. See the third part of this series of papers.

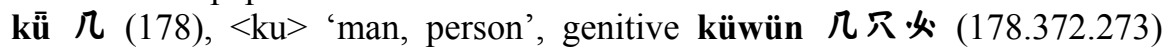
$<$ ku.u.un $>$ (K56-57, in D and X 24 times,WJ75) $\mid$ Mo kümün > küwün > kün, Da huu, dial kuu 'person', HN kü̈̈n 'person, human being', DaE xu:, DaTs xuu, Sh 101: küwün || The Dagur data show that as the Khitan word it has a long vowel and it has 
lost its final $-n$. (427) seems to be a pleonasm, pointing to the male character of the concept. This may have importance, because the word had the original meaning 'human being, person', and the female form was later formed with a diminutive, see Mo keüked 'child', keüken 'girl, daughter'.

The graphic pairs $<$ car $>$ 旺 (183) and $<$ car $>$ (431) also belong to this group. The graph (431) occurs only in names, sometimes written <car.a $>$ 国 (431.189) (X15-3, 1910, 38-21, 46-23, D13-8).

The graphs $<\mathrm{am}>$ 乃 (184) and $<\mathrm{am}>$ 乃 (185) occur in word initial position. We find amilaga'ai 乃夾走 ₹ (184.261.051.122) < am.l.ha.ai> 'to give life, give birth' (X26-11) | Mo amila- and in X34-20<am> ß (185) is the first graph of the name of a mountain.

The graphs $<\mathrm{lu}>$ 支 $(208)$ and $<\mathrm{lu}>$ 先 (209) represent the cyclical sign 'dragon' or 'serpent'. According to Kane the form with the dot (209) "seems to be a misinterpretation" (K60). There does exist also an allograph $<\mathrm{lu}_{2}>$ 皮 (064).

The graphs 仗 (221) and 伏 (222) represent the palatalised /n' (in other transcriptions $\tilde{n})$. 伏 (222) frequently occurs in word initial position, while (221) has not been found in that position. In word initial position, in many cases 伏 (222) has to be $\mathrm{read} / \mathrm{ni}$ / or more probably /ńia/ or /ńio/ as in <ńia.qa > 伏 カ (222.168).

ńiaka 伏力 $(222.168)<$ ńia.qa > 'dog' $(\mathrm{K} 2,19,93),<$ noxi> $(\mathrm{C} 107)$, Liao shi niehe 捏褐 MCh niat.xhat | Mo nokai < *nokai, Da nohe, HN nokai, DaE noy ${ }^{w}|| \mathrm{Cf}$. Tabgach *naxan <*niak +gan <*kan 若干 (Vovin 2009, pp. 199, 203), Sh (105 ńaq). For the reading /qa/ of (168), see baka above.

More complicated is the question how the graph has to be read if it is in final position. In many cases it represents a simple palatalised /n', in other cases /-in/, but Khitan second names ending in 伏 (222) are transcribed with Chinese syllables having the final in and transcribed by Kane $(2009$, p. 61) as <iń $>$. One has the impresson that 伏 in final position, if ending a Khitan word, has a morphological function: $<$ a.am.an $>$ (D35-6) and <a.am.ń> (X28-39, 45-9).

The graphs 仕 (223) and 任 (224) represent both a syllable like /mu/. (224) also occurs as word initial (X32-4) in the complex $<$ mu.u.ji $i_{3}$.en $>$ which seems to be the genitive case of muji.

muji 任及㜾/㢩/约 $(224.131 .152 / 153 / 337)<$ mu.u.ji > 'great, sacred, holy > emperor' (X32-4), and in a unit where the last two graphs are not readable (X36-1), it is most probably the same word. Also mo muji 叉及任及㜾 (133.186.224.131.152) $<$ m.o mu.u.ji $>$ 'the great sacred, holy' (K50). In his work on the Tabgach language, Ligeti $(1970,304)$ dealt with the title moti bi 莫堤 比, which he reconstructed as *modi bi 'chef militaire de province' and connected it with Mo muji 'province, region', supposing the change $-d i->-j i-$, while bi occurs in many other titles as well, but its identification has not yet been made. The text of X23-4 runs: < ...mu.u.ji eu.uni...> where muji has the genitive marker. The word <eu.uni> 杏 (067.059) has to be a title, something like ewüni. Further research is needed, to accept or to 
reject the idea that the Tabgach word and its LMo form muji 'region, province' and the Khitan word muji in the above cited texts are the same words ${ }^{11}$.

In the case of the graphs $<\mathrm{pu}>$ 分 $(241)$ and 分 $<\mathrm{fu}>(242)$, the graph with the dot seems to mark a foreign /f/. According to Kane (K63) Khitan did not have /f/ as initial, and thus transcribed Chinese $/ \mathrm{f} /$ sometimes by $<\mathrm{p}>$ in other cases by $<\mathrm{f}>$. This may be the case e.g. in

püšin 分忝仗 $(241.033 .221)<$ pu.ši.iń> 'madame, Ch 夫人 furen' EMCh puă, LMCh fjyă, fuə̌ + EMCh nin, LMCh rin (K23, 39, 62, 104), <pu.ši.ń> (Sh 106, WJ 53, D8-19/21, D9-1/4)| MMo SH hüjin || Sh is right, (033) is here not /is/ but / ši/. (033) and (221) have dotted forms (034) 忝 and (223) 伏 resp. In this case the dot in 分 $<\mathrm{fu}>$ (242) marks a phonetic peculiarity, existing in Chinese but not in Khitan as in the case of $\dot{\boldsymbol{\chi}}<\check{\mathrm{Z}}>$ (330) above, p. 122.

The graph <ui $>$ 夾 (262) can occur independently as a word representing Khitan

üyi(l) 炎 (262) <ui> 'matter, affair' (K106, 111, D5-1,17-15, 32-3, 34-4, 3720, X3-4, 5-23, 14-21, 26-14, 37-1, 44-6) and has a dotted pair $<$ ui $^{\mathrm{O}}>$ 炎 (263) used only in Chinese transcriptions for several Chinese forms of wei (see WJ191-192), in names, and in titles as taiwei 太尉 'grand commandant' (X18-30). We have to mention that in these cases wei is a part of a name or a title of a male person.

The graph <ie > 文 (326) occurs as word initial; 文 (327) does not occur in this position. However, (327) occurs in the Khitan transcriptions of Chinese -ien rhymes and also in Khitan words in non-initial positions, most probably with the main vowel [a] (K74), because the syllables co-occurring with it contain an /a/ vowel. But this is the same case as with (326), which is followed by $<1$.ha $>$ and $<$ l.un $>($ WJ357).

The graphs $<$ hong $>$ 王 (381) and $<$ hong $_{2}>$ 主 (328) are also related; the second is dotted, though the dot is above the graph. (381) does not occur in word initial position, (328) occurs as an independent word. The latter has an allograph $<$ hong $>$ 主 (075), and both have the meaning 'emperor' as in hongdi.

hongdi 主王 $(328.037)<$ hong.di> 'Emperor' (K95, D3-23/27) $\leftarrow$ Ch huangdi 皇帝 LMCh xhuay tiaj. The LMCh [xh] evolved from an EMCh $[\gamma]$ and this, or a voiced $\chi$ is the value of $h$ - in the Khitan transcription of this title.

Theoretically 王 (381) should be the female counterpart, the Empress or Queen, but it is possible that the graph $\underline{\mathbf{x}}$ is a simple mistake.

The graphs $火(344)<u d>$ and $*(345)<u n g>$ seem to differ only in one dot or a small dash, while for ung we find also the allographs $火(346)<$ ung $_{2}>$, 火 (106) $<$ ung $_{3}>$ and $<$ úng $>$ 火 (357). In these cases (344) most probably has nothing to do with the graphs $(346,106)$.

The graphs 兄 (370) and 兄 (371) both have the meaning 'region', but it is not clear what the distinction between the dotted and nondotted forms is.

${ }^{11}$ By the way, 'holy, sacred' is in Chinese shèng 聖, while 'province' is also shĕng 省 with a different tone. 
As we can see most of the dotted pairs are used for gender differentiation, but not all. One has the impression that dotting is a relatively late feature in the history of KSS. It is in any case significant that the marked pair is the masculine.

\section{Graphs Denoting Numerals}

There exists a relatively rich literature on the numerals of Proto Mongol and Khitan ${ }^{12}$. I will not go here into the discussion of former research.

\section{Remarks on the Numerals}

The ordinal numbers were treated by Kane (K143-144). There is a miswriting in his table, in place of $<$ úr $>$ the consistent transcription is $<$ ur $>$ of 化 (236).

\section{One モ (026), モ (027)}

In some languages the numeral for 'one' is a newcomer ${ }^{13}$. This is due to different uses of the numeral in the syntax. There are different words in Khitan which seem to fill the function of the numeral 'one'.

nai 穴 (332) <nai> 'first, head; official' (K75, 109, D4-4/6, Sh2), plural naid 穴灻 (332.350) <nai.d>, gen. <nai.en> 'officials' (K101) \| the function of nai may be similar to OT baš 'head, leader, the first one'. In LMo nai has the meaning 'friendship', but it may be a different word.

mas モ, モ $(026,027)<$ mas $>$ 'one' (K110) <masai $>$ (C107), according to Aisin Gioro (2012) $€(027)$ has to be read am. According to Kane, in the emended sections of the Dazong inscription任企全 $224.257 .244 .334<$ mu.em.se.gi> was rewritten as $€$ 千 $九<$ ONE.se.gi $>$ suggesting that $€$ was pronounced the same as $<$ mu.em $>$ or perhaps *mem (K110) || see perhaps Mo emüne or more probably emünesi 'front, anterior'. The latter is in MgrH musíi, and in MgrM meši . However, see also masku.

masku 叉冬余/ 太 $(133.174 .246 / 118)<$ m.as.qu/qú- 'first' (K48, 50, X10-20).

The logograph ONE is also used as general subject: モ伊与 (026.238.100) $<$ ONE BORN.en... > 'One is born into [disasters and good fortune]' (K155).

${ }^{12}$ See among others Laufer (1921), Poppe (1955), Ji Shi (1986), Liu Fengzhu (1988a), Toyoda Gorō (1992), Chen Naixiong (1992), Chinggeltei (1997b), Kara (1997), Toyoda Gorō (1998a), summarised by Kane (2009), Jacques (2010), and most recently Janhunen (2012, pp. 1213). A. Hölzl (2015) discusses the numerals in Alchuka, a newly discovered and now already extinct language, which seems to be close to Manchu and Jurchen. This language, like other ManchuTungus languages, preserved old loans from Mongolic, among others the numerals.

${ }^{13}$ On the Indo-European words for 'one', see Gamkrelidze-Ivanov (1995, pp. 740-741). Hungarian egy 'one' goes back to a demonstrative pronoun. 
Two 조(134), 조 (135)

The cardinal numeral for 'two' is:

jür 机化 (162.236) <či.ur> 'two' (K50, Sh2, D16-12, 24-20, X9-15, 15-2, 171, 19-30 and passim) | Mo jirin 'two (women)', jirin sedkiltü 'disloyal, i.e. who has a double soul', jirmüsün 'pregnant', jirim 'either one of the two leather straps on the left side of the saddle', jitüger (<*jirtüger) 'jealousy, hate; invective used by wives of a polygamous marriage, in referring to each other', jitüger eme 'the other wife (term used by the other wife in polygamous marriage in reference to another), jirgugan 'six (twice three jir+gur, cf. also WJ 56), HN ji- 'two' in: jitüer 'second, co-wife', jitügen 'competition', the Mo base is not *ji- but *jir $\|$ There is a difference in the vocalism. The Mo word has /i/, the Khitan /ü/. As we shall see, /r/ may have been a very old suffix. ${ }^{14}$

\section{Three 圣 (166), 圣 (167)}

The Khitan cardinal numeral for 'three' is gur. In the Romanisation we find $<\mathrm{h}>$ which denotes a back vocalic guttural, in some cases even a fricative, but here beyond any doubt it is a stop, though in the Gaoshi inscription of unknown date we find the initial $\mathcal{x}(341)<\mathrm{x}>$.

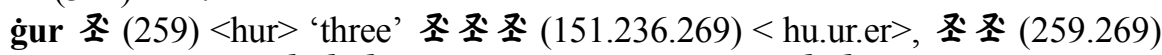
<hur.er> 'third, masc.', 조조ㅈㅗㅗ 151.236.219) < hu.ur.én>, 조종 (259.218) <hur.én> (K53, 54-55, 66, 121, 143, D9-5), 조조종 (340.236.219) <x.ur.én> (Gao inscr. K143) 'third, fem', <үur> (C107) | Mo gurban, Da guarebe, HN gurban, DaE $g^{w}$ arba, $g^{w} a r b ə n, g^{w} a r a b$.

\section{Four 조 (368), 조 (369)}

The cardinal numeral for 'four' is in Khitan dür written in different ways. The graph (260) hitherto occurred only in this word, and was read $<$ dur $>$ and $<\mathrm{t}_{2}>$.

dür 令化 $(260.236)<$ t.ur>, dür 令交 $(247.097)<$ t.úr $>$ (X35-11), dürü 爸㐫 及 $(254.097 .131)<$ d.úr.u>, dürüg 今化多 $(247.236 .172)<$ t.ur.uh $>$ 'four', (K98, Sh2: dur $),<$ dur $>$ (C 107), dürüer, dürüen 今化爻 $(247.236 .269)<$ t.ur.er $>$ masc, 令 化当 $(\sim 2361)<$ t.ur.én>, 爸化与 $(254.236 .361)<$ d.ur.én> fem 'fourth' $(K 79,98)$, $<$ duruwei $>$ (C107) | Mo dörben, Da durube, HN dörben 'four', DaE durb ${ }^{w}$, durbun \| The initial is $<\mathrm{d}>$ in the inscriptions. Zhi (1094), Yong, Gao (see K143-144) and has to be read $d$-also in the other inscriptions. As we shall see in the third part of these studies, the alternation $t \sim d$ is orthographic, not phonetic.

${ }^{14}$ The vowel of the Khitan word for 'two' is a closed labial sound. From the script we cannot decide whether it is a front or back vocalic one. During the session in Academia.edu, A. Hölzl and V. Ponaryadov argued that the vowel is back vocalic. My answer is that from the graphs we cannot decide. But since the whole system of the Khitan language points to the existence of a frontback opposition (see also Kane 2009, pp. 30-32), we can reconstruct here a front */ü/. 
Five 조(029), 조(030)

The Khitan word for the cardinal numeral 'five' is taw:

taw 戈 $(029)<$ tau $>$ 'five' $(\mathrm{K} 19,24,38,98),<\mathrm{t}$ ' $\alpha \mathrm{u}>(\mathrm{C} 107)$. There exist a unit $<$ ta.u $>$ 仍 (229.131) which seems to be the transcription of the same numeral (D29-16, X32-26, 34-3) | Liaoshi tao 討, LMCh thaw | Mo tabun, Da taau, HN tabun, DaE ta: wu(n). tadog்o, todog்o 今.5. 币及圠币 $(247.099 / 016.186 .076)<$. t.ad/od.o.ho> 'fifth' (K97), <t'owo'oi > (C107) | Mo tabudugar, Sh: *tow- \|| The ordinal suffix [-dogo] is reminiscent of Mo -dugar.

\section{Six 圣 (085), 圣 (086)}

Toyoda Gorō (1998) tried to reconstruct Khitan 'six' as *jirgu and 'eight' as *nai, which seems to be logical, but no convincing data has appeared, as remarked by Kane (K117). I have to add that in Khitan 'two' is jür and not jir. Mongolian jirgugan 'six' is, as it was stated by many scholars (Poppe 1955, pp. 245 etc.), two times three, jir + gurban, and may be a later formation. Nugteren (2011, p. 388) supposes for the QinghaiGansu Mongol languages here an unknown suffix ?-gUAn, but this is not necessary. In any case Khitan may have had another word for 'six'. To the numeral 'six', see also Mo jig̈̈ 'descendant in the fifth generation', i.e. the 'sixth' (<*juirgü/jirgu). This may be of importance, because this form is front vocalic, while all other data for Mo 'six' are back vocalic. Chinggeltei (2002a, p. 107) reconstructed for Khitan *nir for 'six' while Kane (117) *nil. These are based on Manchu-Tungus *nimun 'six'. The numeral 'sixty' in Mo is jiran, where the final part may be the old word for 'ten/teen' -on (cf. OT on 'ten', see Poppe 1955, p. 247). This would suggest a word like *jir for 'six', but this was the Mongolian word for 'two' as we have seen. The ordinal of Khitan 'six' does not help, it is 灰公 $(086.341)<$ SIX.er>. ${ }^{15}$ For the time being the best candidate is *nir.

\section{Seven 조 (141), 圣 (441)}

The cardinal numeral 'seven' is dalo:

dalo 圣圣 $(171.313)<$ da.lo> 'seven' $(\mathrm{K} 72,115),<\mathrm{dol}>(\mathrm{C} 107)$, daloer 圣 圣圣 $(171.313 .269)<$ da.lo.er> 'seventh, masculine' $(K 72,115),<$ doluwei $>(C 107) \mid$ Mo dolugan, Da doloo, HN dolaan, DaE dols, dolsn 'seven'. See further Mo dalan, $\mathrm{HN}$ dalan ( $<*$ daluan) 'seventy'.

Eight 垔 (007), 王 (008)

Ji Shi and Chinggeltei (cited by K36) suggested for 'eight' *naim. From the point of reconstruction I do not see any reason for the final $-m$, because in Mo naiman the last part -man is the same petrified suffix as -b/gAn in gurban, dörben, jirgugan, dolugan, yisügen and arban, only nasalised after a nasal initial: naiman < *naiban. Mo 'ninety' is nayan. All Khitan numerals lack the suffix *b/gAn. Based on these facts one would

${ }^{15}$ Hölzl (2015), as did earlier Kane, suggests a final - $l$ based on Jurchen and Alchuka data. These $l$ s may have been substituion for $-r$, which is present in most of the Proto Mongolic numerals. 
expect for Khitan *nayi or even neyi. The masculine ordinal of 'eight', 'eighth', is 王化 定 (008.235.269), that is <EIGHT.ri.er> (K143). This points to a possible form *nayirier or *neyirier. Here - $r$ - would be the same petrified suffix as in jür, gur, dür etc. The expected form of Khitan 'eight' would be then *nayir/neyir. For the time being we have to wait for new data.

Nine 忝 (033), 忝 (034)

iši 忝 $(033)<$ is> 'nine, fem.' the masc. form is 忝 (034) (K24, 109, D49-8, 51-8, $\mathrm{X} 4-21,6-8,28.10),<\mathrm{is}>(\mathrm{C} 107) \mid$ Mo yisün, Da ise, HN yesün < *yersün, DaE is, yis, Sh: *iš $i \mid$ According to $\mathrm{HN} *$ yersün, the *-r-is reconstructed by $\mathrm{HN}$ from yeren 'ninety' and is preserved in one of the Baoan dialects. In another Baoan dialect the $y$ is absent as in Da $\|$ The $y$ - in Mo may be secondary, and originally 'nine' was *isün, which may have come from an earlier **irsün, where - $\ddot{u}$ is the same suffix as $-u n$ in tabun. The Khitan graph occurs also in the Khitan clan name 天呑 (033.334) $<$ is.g.i $>$ which occurs in the Chinese transcription as Yishiji 己室乙, the initial of the first word had in LMCh a glottal stop Pit, the second word was $̌ i$, that is, the name had to be *Išigi or the like. This is in favour of the proposal of Shimunek to read $i \check{s} i$ or $i s$ for the numeral 'nine'. I would opt for $i \check{s} i$. The $<\breve{s}>$ may be, however, secondary in the case of $<\mathrm{isi}>><\mathrm{iši}>$. According to Janhunen (2012, p. 13) the Mo form *yersün is an innovation and cannot be connected with Khitan *isi. I think, that if we depart from a form **irsün, all forms can be connected. The ordinal form is išider 忝全 $(033.254 .341)<$ iši.d.er> (D2-15).

The syllable is also present in the name <is.iú.ih/ih $>$ 忝岀洦/而 (033.289.338/455) 'Išiyuig' in D1-15, 51-15 as the name of the scribe of the Xiao Dilu inscription. The name may be of Biblic origin and perhaps Nestorian.

The graph occurs also in the Khitan transcription of the Chinese title

pushi 分忝 <pu.is> is more correctly <pu.ši $>$ 'Chinese title', fushi 副使 (WJ52, D1-5).

It occurs further in püšin, fušin 分忝 伏 (241.033.221) see above, p. 125.

Ten 白 (240), 分 (422)

The Khitan pronunciation of the word for 'ten' was hitherto unknown. I suggest par or para. This occurs as 业本/布 $(295.084 / 397)<$ p.ra/ra ${ }^{\circ}>/$ para/. It is present in two inscriptions, in the Xiao Dilu inscription (AD 1117) we read:

1. 止布|全九交知平亚中 (D32-11-14)

2. (295.084| 245.334.097.205| 161.366.051.122)

3. <p.ra ú.g.úr.de au.ul.ha.ai>

4. para ugurde awulgai

5. [the Emperor] let [him to be] appointed to the Ten Ugurs'.

${ }^{16}$ In line 1 the text is given with Khitan graphs, in line 2 the numbers of the graphs in the List, in line 3 the transcription of the graphs according to the List, in line 4 suggested reading of the Khitan texts, in line 5 the English translation of the Khitan tetxt. 
Table of the graphs

\begin{tabular}{|c|c|c|c|}
\hline Number & $\begin{array}{c}\text { Graph } \\
\text { (No. in List) }\end{array}$ & Reading & $\begin{array}{c}\text { Cardinal numbers } \\
\text { in KSS }\end{array}$ \\
\hline ONE, $\mathrm{m}$ & モ (027) & & \\
\hline ONE, $\mathrm{f}$ & モ $(026)$ & & \\
\hline TWO, m & 叒 (135) & \multirow{2}{*}{ jür } & \multirow[t]{2}{*}{ jür机化 $(162.236)<$ či.ur> } \\
\hline TWO, f & 조 (134) & & \\
\hline THREE, $\mathrm{m}$ & 包 (167) & \multirow[b]{2}{*}{ gur } & \multirow[b]{2}{*}{$\dot{\text { gur }}$ 众 $(259)<$ hur $>$ /gur/ } \\
\hline THREE, $\mathrm{f}$ & 包 (166) & & \\
\hline FOUR, $\mathrm{m}$ & 飞 (369) & \multirow{2}{*}{ dür } & \multirow{2}{*}{$\begin{array}{l}\text { dürü } \\
\text { 父厽及(254 .097.131) } \\
\text { <d.úr.u> }\end{array}$} \\
\hline FOUR, $\mathrm{f}$ & モ (268) & & \\
\hline FIVE, $\mathrm{m}$ & 戈 (030) & \multirow{2}{*}{ taw, LSh tao 討 } & taw 仍及 $(229.131)<$ ta.u $>$ \\
\hline FIVE, $f$ & 毛 (029) & & \\
\hline SIX, m & 灰 $(085)$ & & \\
\hline SIX, $\mathrm{f}$ & 灰 $(086)$ & & \\
\hline SEVEN, $\mathrm{m}$ & 尻 (441) & \multirow{2}{*}{ dalo } & \multirow{2}{*}{$\begin{array}{l}\text { dalo 久 \# (171.313) } \\
<\text { da.lo }>\end{array}$} \\
\hline SEVEN, f & 尻 (141) & & \\
\hline EIGHT, $\mathrm{m}$ & 王 (008) & & \\
\hline EIGHT, $\mathrm{f}$ & 王 (007) & & \\
\hline NINE, $m$ & 忝 (034) & \multirow{2}{*}{ iši } & \\
\hline NINE, $\mathrm{f}$ & 忝 (033) & & \\
\hline TEN, $\mathrm{m}$ & 分 (422) & \multirow{2}{*}{ para } & $\begin{array}{l}\text { para } \\
\text { 业有 }(295.397)<\text { p.ra> }\end{array}$ \\
\hline TEN, $\mathrm{f}$ & 分 (240) & & $\begin{array}{l}\text { para } \\
\text { 业本 }(295.084)<\text { p.ra }>\end{array}$ \\
\hline
\end{tabular}




\section{denoting numerals}

\begin{tabular}{|c|c|c|c|}
\hline Ordinal numbers in KSS & $\begin{array}{l}\text { Ordinal number } \\
\text { reading }\end{array}$ & Pronunciation & $\begin{array}{c}\text { Mongolian simple } \\
\text { /decade }\end{array}$ \\
\hline $\begin{array}{l}\text { 叉及 }(132.186) \\
\text { 叉各欠/余 }(132.124 .169 / 24) \\
\text { 穴 (332) }\end{array}$ & $\begin{array}{l}<\mathrm{m} . \mathrm{o}> \\
<\mathrm{m} . \text { as.qo/qu }> \\
<\text { nai }>\text { 'first, head' }\end{array}$ & & \multirow[t]{2}{*}{ nigen } \\
\hline 叉冬丈 (132.124.117) & $<$ m.as.qú $>$ & & \\
\hline $\begin{array}{l}\text { 本化爻 }(162.236 .269) \\
\text { 玄化爻 }(104.236 .269)\end{array}$ & $\begin{array}{l}<\text { c.ur.er }> \\
<\text { dz.ur.er }>\end{array}$ & jürer & \multirow{2}{*}{$\begin{array}{l}\text { jirin, qoyar/ } \\
\text { qorin }\end{array}$} \\
\hline 机化与 (162.236.161) & $<$ c.ur.én $>$ & jüren & \\
\hline 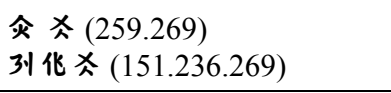 & $\begin{array}{l}<\text { hur.er }> \\
<\text { hu.ur.er }>\end{array}$ & gurer & \multirow{2}{*}{$\begin{array}{l}\text { gurban/ } \\
\text { gučin }<* \text { gurčin }\end{array}$} \\
\hline 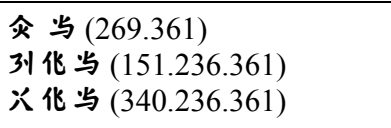 & $\begin{array}{l}<\text { hur.én }> \\
<\text { hu.ur.én }> \\
<\text { x.ur.én }>\end{array}$ & guren & \\
\hline $\begin{array}{l}\text { 今化爻 (247. 236.269) } \\
\text { 爸化爻 }(254.236 .269)\end{array}$ & $\begin{array}{l}<\text { t.ur.er }> \\
<\text { d.ur.er }>\end{array}$ & dürer & \multirow{2}{*}{$\begin{array}{l}\text { dörben/ } \\
\text { döčin }<* \text { dörčin }\end{array}$} \\
\hline $\begin{array}{l}\text { 令化当 }(246.236 .361) \\
\text { 爸化当 }(254.236 .361)\end{array}$ & $\begin{array}{l}<\text { t.ur.én }> \\
<\text { d.ur.én }>\end{array}$ & düren & \\
\hline $\begin{array}{l}\text { 今币及圠 }(247.016 .186 .076) \\
\text { 今市及圠 }(246.099 .186,076)\end{array}$ & $\begin{array}{l}<\text { t.od.o.ho }> \\
\text { Sh: }<* \text { t.ow.o.ho }> \\
<\text { t.ad.o.ho }>\end{array}$ & todogio & \multirow[t]{2}{*}{$\begin{array}{l}\text { tabun/ } \\
\text { tabin }\end{array}$} \\
\hline 今な及雨(246.099.186.018) & $<$ t.od.o.in $>$ & todoin & \\
\hline & & & \multirow{2}{*}{$\begin{array}{l}\text { jirg்ugan. } \\
<* \text { jirgurban/jiran }\end{array}$} \\
\hline & & & \\
\hline & & & \multirow{2}{*}{$\begin{array}{l}\text { dologan/ } \\
\text { dalan }\end{array}$} \\
\hline & & & \\
\hline & & & \multirow{2}{*}{$\begin{array}{l}\text { nayiman/ } \\
\text { nayan }\end{array}$} \\
\hline & & & \\
\hline & & & \multirow{2}{*}{$\begin{array}{l}\text { yisün }<* \text { yersün/ } \\
\text { yeren }\end{array}$} \\
\hline & & & \\
\hline & & & \multirow{2}{*}{ (h)arban } \\
\hline & & & \\
\hline
\end{tabular}


According to WJ 112 in <ú.g.úr $><u ́$ $>$ stands for Chinese Wu 吳 and g.úr is the translation of Chinese guo 國 'state', that is <ú.g.úr.de $>$ woud have the meaning 'to the State of Wu'. For the word $<$ p.ra $>$ no remark is offered, for $<$ au.ul.ha.ai $>$ WJ wrote "unclear, but perhaps 'placed'. The Kingdom of Wu was a small kingdom which existed from 902-937 in the southeastern part of China" (WF 562n), therefore this interpretation can be excluded with great probability for chronological and geographical reasons ${ }^{17}$.

The second text is in the Yelü Xiangwen inscription (1091):

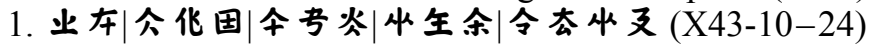

2. (295.084| 252.236.309|244.125.347|261.196.246|247.112.261.144)

3. <p.ra $\bar{o}_{2}$.ur.hó s.aū.oi l.bu.qu t.ge 2. l.un>

4. para ogurgo sawoi Elbuqu tegelün

5. 'While resting at the Ten Ogurs Elbuqu died (went up)'.

The different writing of the name Ugur or Ogur seems to be quite normal. There does exist a large literature on the Ogur tribal name which was originally Ogur and later became Ugur. I will come back to the absence of marking the guttural stops and fricatives. $<$ hó $>$ is a locative suffix, occurring at the end of nominals.

There exists an expression which occurs many times (D12-13, 25-25, X7-21, 12-29, 16-7): <mo.d/t p.ar.TWO> 万企/令步圣 (021. 254/247. 295.123134) '(he had) two wives'. What may be the word par here? According to WJ84-85 mod par seems to be the plural of moku 百几 (021178), and $k u$ is 'person'. According to WJ par is an irregular plural form of $k u$, a cognate to Mongolian (h) aran/(h)arad 'people'. This type of irregular plural form exists e.g. Russian čelovek, plural ljudi 'man, person, human being'. But one would expect in this case a normal plural, like *parad as in mod. I suggest here the function of a count word or classifier, as it is frequent in Chinese and other East Asian languages. The phrase mot par TWO can be translated as '(he had) as to their number, two wives'. If this hypothesis can be proven, *para originally would have been a count word. Later it became the count word par excellence, i.e. 'ten'. In Mongolian it acquired the suffix $-b A n$ : par+ban $>$ harban $>$ arban Here I would remark that many of the numerals end in $-r$ (see also Janhunen 2012, p. 13): *jür 'two', *gur 'three', *dür 'four', *jirs 'nine', *par 'ten'. -r is a residual form of an earlier suffix (see also Mo qoyar). Thus one would expect for 'ten': par. The ordinal form is TEN.d.er (D2-9).

\section{Eleven 圣 / 圣 $(240 / 422)+$ モ/ モ $(026,027)$}

Eleven is TEN+ONE (X2-3, EX4-9). Here we learn only the structure of the Khitan numeral for eleven, as Mo arban nigen 'eleven'. A few other numerals with similar structure are: twenty-three 丁包 (002.166) (K124), sixty-seven X/义 (266/267) + 尻/ P $(141 / 441)(\mathrm{L} 26+34)$ and so on.

${ }^{17}$ On the Ten Turkic Tribes see WF pp. 86, 471. 
Twenty $丁(002)$

Kane (K35) quotes Ji Shi (1986) who noted a reference to an early Khitan leader, named Zhou-li Hun- $a$ 書里昏阿. About this person the Qidanguozhi tells us that he kept twenty sheep/goats ${ }^{18}$, every day he ate nineteen, only leaving one, the next day again there were twenty, this continued day after day, every day was like this. Ji shi suggested that zhou 書 might be a mistake for hua 畫, which would be reminiscent of Mo qori, qorin 'twenty' and hun-a to qoni(n) 'sheep'. May be we have not a mistake in the rendering of the first syllable of the Khitan name. zhou 書 goes back to a LMCh triw and an EMCh truw. If used for transcription the initial represented a foreign affricate $/ \check{c} /$ or $/ \tilde{j} /$. This means that we have in case of zhouli 書里 the transcripition of a Khitan form jüri. Since 'two' is in Khitan jür, one would expect jüri for the Khitan word 'twenty' or perhaps jürin. This ending would be the same as in Mo tabin 'fifty'. The final $-n$ may have been lost in Khitan.

We find the following text: $<$ da.ha.ar o.ju. DAY (292).u $>$ 'the coffin was closed [on the] day (292)', (K155), where 3 (292) has to be a numeral, hitherto not identified. Theoretically it may also be something as the "middle", "full moon" etc., but this is unlikely, There are three graphs following each other which have neither known reading nor meaning in the List 水, 軏, 炎 $(291,292,293)$. We see that the first graph occurs also as the upper part of the second and the third. It is possible that all three denote numerals, may be, but not sure, $21,22,23$ or perhaps as in Old Turkic they may also denote $11,12,13$, that is the first, the second, the third of the second decade. At least (292) has to be a numeral which may occur as the number of a day in a month.

\section{Thirty $レ(211)$}

The Mongolic word for 'thirty' is known from the Chinese geographical work Yuan he jun xian tou zhi, compiled in 813-814, where it is the local name of a mountain $30 \mathrm{li}$ away from the centre. It has been dealt with by Pelliot (1929, pp. 250-252) and by Ligeti (1970, p. 290). It appears in the form he zhen 纥真 EMCh yat, LMCh xhat

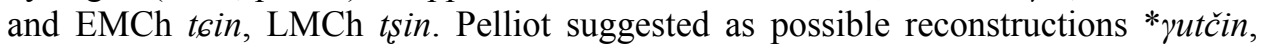

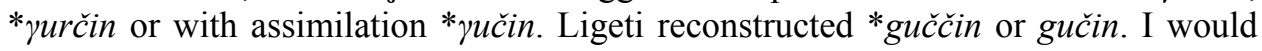
prefer *gurčin. The final Chinese $-t$ is reflected in this time in the Uygur and Tibetan transcriptions by $-r$ (see Csongor 1952, 1954; Tokio Takata 1988). In the given case, the Chinese he is usually transcribing the second part of the tribal name Uygur as mentioned by Pelliot (1929, p. 252). It is possible that Mongolic *gurčin goes back to an earlier * gurtin. The form of the word for ' 30 ' can be reconstructed in ManchuTungus as *gutin (see Laufer 1921; Miller 1975; Poppe 1979; Cincius 1975, p. 175, Doerfer 1985; Janhunen 1993; Hölzl 2015), while the Jurchen form is *gušin (Kane 1989 , p. 364), these forms are loans from early Mongolic. Though the Chinese data are

\footnotetext{
${ }^{18}$ In the Chinese text there is yang 羊 'sheep'. Ch hun 昏, MCh xun may be connected with Mo qoni(n), but the final $-a$ has no explanation yet.
} 
about hundred years older than the period the Khitans occupied their new territory in North China, it is possible that the Mongolic name is of Tuyühun origin, it gives some support to suppose that the Khitan word for '30' was also something like *gurčin.

The decades over thirty seem to be simple logographs: forty $了$ (145), fifty $乙$ (155), sixty 圣 (266), 조 (267) 조 (424), seventy 조 (300), 조 (301), eighty \ (449). The word for ninety has not yet been found in the texts. It is highly probable that dotted forms for the decades will also crop up.

\section{Hundred}

The Khitan word for 'hundred' is:

jaw $3_{3}(015)<$ jau $>$, 'hundred' (K2, 37, 102, D5-4, 19-8, 38-11) <dzaw > (C107) Liaoshi zhao 爪 | MMo jawun, Mo jagun, Da jau, HN jaun DaE jau. \| All Mongolian languages and dialects have a final $-n$ with the exception of Dagur and Khitan. The expression $<$ ku.BORN.i jau.en eu.úr $>$ is according to WJ (p. 204) a proverb-like expression, equivalent to the Chinese expression rensheng baisui 'human life [is equal to] a hundred years'. In this case -en is not the genitive suffix, but represents a final $-n$.

\section{Thousand 圣 (207)}

Chinggeltei (2002a, p. 107) and Kane (K122) suggest that the Khitan word be read as 'thousand' min:

min 买 $<\mathrm{min}>$ (207), 买夹穴爸 $(207.011 .332 .254)<$ min.an nai:d > 'leaders of a thousand' (K60, 122, D40-14, 46-9, X47-4)，矢林的 (187. 207.122.140.336) $<$ min ai.en $\mathrm{gi}_{2}>$ '?' (D40-1/22), 矢午 $(207.195)<\mathrm{min}$. CHIEF) 'the leader of a thousand' (D46-9/12), <min> (C107) | Mo minggan, Da miange, HN mïngan, DaE $m^{v}$ ańga $\mid \leftarrow$ OT mïy, b̈̈y.

Ten thousand 조 (187), also 'a great amount' and similar:

Tum 조 (312), 圣 (406) < tum> 'ten thousand' (K72, 120), 圣丹 (134.312) < Twotime> 'twenty thousand, two "ten thousand"' (Renxian 49)| Mo tümen, Da tume. HN tümen, DaE tum $\|$ Only Da has the word without final $-n$, the graph occurs also in names such as Tümür.

tümür 丹文 (312.097) <tum.úr> 'iron' (D40-13, 43-1), 及交交 (312.131.097) <tum.u.úr> (X47-9), 丹尺交 (312.372.097)<tum.ū.úr> (X17-13, 38-36), in the name Tümür Tunga 夜令为 $(312.097 .247 .357 .189)<$ tumu.úr túng.a> in the Yelü Renxian inscr. (WJ119)| Mo temür, HN temür, Da 'iron' is *kasu > Da kasoo, DaE kasə:. On the latter see Ligeti (1950-1951).

As it has been stated by most scholars, latest by Janhunen (2012, pp. 12-13), the Khitan and the Mongol numerical systems are genetically related. Only in the high numbers as thousand and ten thousand do we find loanwords. 


\section{Abbreviations}

BaoD = Dahejia (or Jishishan) Baoan (after HN)

BaoŃ = Ńantoq subdialect of Tongren Baoan (after HN)

$\mathrm{C}=$ Chinggeltei (2002a)

$\mathrm{Ch}=$ Chinese

$\mathrm{D}=$ Xiao Dilu inscription in WJ

$\mathrm{Da}=$ Dagur according to Martin (1961)

$\mathrm{DaE}=$ Dagur according to Enkhbat (in $\mathrm{HN}$ )

DaTC $=$ Dagur after Tumurdej - Cybenov (2014)

Dgx $=$ Dongxian $($ after HN)

$\mathrm{EMCh}=$ Early Middle Chinese according to Pulleyblank (1991)

$\mathrm{EX}=$ Eulogy for Empress Xuanyi, ed K pp. 214-223

$\mathrm{EYu}=$ Eastern Yugur

$\mathrm{Gu}=$ The Gu Yelü shi mingshi Inscription AD 1115 (in K)

$\mathrm{HN}=$ Nugteren (2011)

$\mathrm{K}=$ Kane (2009)

$\mathrm{Kgj}=$ Kangjia (after HN)

$\mathrm{Kh}=$ Khalkha Mongol (Luvsandendev 1957)

KLS $=$ Khitan Large Script

KSS $=$ Khitan Small Script

$\mathrm{L}=$ The Langjun inscription in $\mathrm{K}$

L2 = The Langjun inscription according to Sh2

List $=$ List of KSS graphs as in WJ

LMCh $=$ Late Middle Chinese according to Pulleyblank (1991)

Mgr = DeSmedt - Mostaert (1933)

$\mathrm{MgrH}=$ Huzhu dialect of Monguor (after HN)

MgrM = Minhe dialect of Monguor (after HN)

Mo $=$ Literary Mongolian according to Lessing (1960)

$\mathrm{PKh}=$ Proto Khitan

Rykin $=$ Rykin (2014)

$\mathrm{QG}=$ The Qinghai and Gansu Mongol languages according to HN

$\mathrm{SH}=$ The Secret History of the Mongols (cited after Rachewiltz 2004)

$\mathrm{Sh}=$ Shimunek (2011)

Sh2 $=$ Shimunek (2014)

$\mathrm{SJL}=$ Sun - Jing $-\mathrm{Li}(2010)$

$\mathrm{Tib}=$ Tibetan

TMR $=$ Tibeto-Mongolica Revisited (Róna-Tas 2014)

WF $=$ Wittfogel - Fêng (1949)

$\mathrm{WJ}=\mathrm{Wu}-$ Janhunen $(2010)$

WOT $=$ Róna-Tas - Berta (2011)

$\mathrm{X}=$ The Yelü Xiangwen inscription in WJ

$\mathrm{Y}=$ The Yelü Dilie inscription in K 


\section{References}

Aisin, Gioro (2012): Reconstruction of Phonetic Values of Khitan Small Scripts and Concerning Problems. Ritsumeikan bungaku No. 7, pp. 1-28.

$=$ http://www.ritsumei.ac.jp/acd/cg/lt/rb/627/627PDF/yosimo to.pdf

Chen Naixiong (1992): Qidan xiaozi shuci yingzi zi tan [On the 'shadow graphs' in Khitan numerals]. Neimenggu daxue xuebao No. 3, pp. 1-8.

Chinggeltei (1997): Qidanyu shuci ji Qidan xiao zi de yanjiu [Khitan numerals and graph combinations in the Khitan small script]. Neimenggu daxue xuebao No. 4, pp. 1-9.

Chinggeltei (2002a): On the Problems of Reading Kitan Characters. AOH 55, pp. 99-114.

Chinggeltei (2002b): Qidan xiao zi shidu wenti [Problems of the decipherment of the Khitan Small Script]. Tokyo.

Cincius, V. I. (ed.) (1975): Sravnitel'nyj slovar' tunguso-man'čžurskih jazykov. Vols 1-2. Leningrad.

Csongor, B. (1952): Chinese in the Uighur Script of the T'ang-Period. $A O H$ Vol. 2, pp. 73-121.

Csongor, B. (1954) Some More Chinese Glosses in Uighur Script. AOH Vol. 4, pp. 251-257.

Doerfer, G. (1985): Mongolo-Tungusica (Tungusica 3). Wiesbaden.

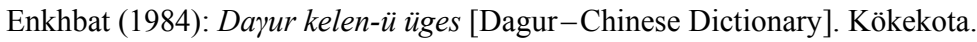

Gamkrelidze, Th. V.-Ivanov, V. V. (1995): Indo-European and the Indo-Europeans. Part I. The Text. Part II. Bibliography, Indexes. Berlin-New York (Trends in Linguistics. Studies and Monographs 80).

Hölzl, A. (2015): New Evidence on Para-Mongolic Numerals (forthcoming).

Jacques, G. (2010): Review on Kane 2009. Diachronica 27, pp. 157-165.

Janhunen, J. (1993): The Teens in Jurchen and Manchu Revisited. Festschrift für Raija Bartens. MSFOu 215, pp. 169-184.

Janhunen, J. (2012): Khitan: Understanding the Language Behind the Script. SCRIPTA 4, pp. 1-36.

Ji Ruhe-Wu Yingzhe (2009): Qidan xiao zi yuanzi zixing guifan yu yunzi zongbiao (The standardisation of the Khitan Small Script character forms and general list of the characters). Nei Menggu Daxue Xuebao (Zhexue Shehui Kexueban) No. 3, pp. 127-132.

Ji Shi (1986): Guanyu Qidan shuci duyin wenti [The question of the pronunciation of Khitan numerals]. Naimenggu daxue xuebao No. 4, pp. 89-100.

Kałużyński, St. (1969-1970): Dagurisches Wörterverzeichnis. Nach F. V. Muromskis handschriftlichen Sprachaufzeichnungen. Rocznik Orientalisticzny Vol. XXXIII, No. 1, pp. 103-140, Vol. XIII, No. 2, pp. 109-143.

Kane, D. (1989): The Sino-Jurchen Vocabulary of the Bureau of Interpreters. Bloomington.

Kane, D. (2009): The Kitan Language and Script. Leiden-Boston.

Kara, G. (1997) Numerals in Kitan. Lunwen yu Jinianwen, Jinnian Qing'ertai jiaoshou congjiao 50 jou bian wenji [not seen].

Laufer, B. (1921): Jurči and Mongol Numerals. Körösi Csoma Archivum Vol. 1, pp. 112-115.

Lessing, F. D. (ed.) (1960): Mongolian-English Dictionary. Berkeley-Los Angeles.

Ligeti, L. (1950-1951): Mots de civilisation de haute Asie en transcription chinoise. AOH Vol. 1, pp. $141-185$.

Ligeti, L. (1970): Le tabgatch, un dialecte de la langue sien-pi. In: Ligeti, L. (ed.): Mongolian Studies. Budapest, pp. 265-308.

Liu Fengzhu (1988): Qidan dai zhong 'liu' de jiedu licheng [The process of the decipherment of the graph for 'six' in the Khitan large script]. Liao Jin Qidan Nuzhenshi yanjiu 2, pp. 71-72.

Luvsandendev, A. (1957): Mongol'sko-russkij slovar'. Moskva.

Martin, S. E. (1961): Dagur Mongolian Grammar, Texts and Lexicon. Bloomington. 
Miller, R. A. (1975): Notes on the క̌ürčen Numerals for the Teens. UAJb Vol. 47, pp. 146-153.

Nugteren, H. (2011): Mongolic Phonology and the Qinghai-Gansu Languages. Utrecht.

Pelliot, P. (1929): Neuf notes des questions d'Asie Centrale. T'oung Pao Vol. 26, pp. 201-265.

Poppe, N. (1955): Introduction to Mongolian Comparative Studies. Helsinki (MSFOu 110).

Poppe, N. (1964): Grammar of Written Mongolian. Wiesbaden.

Poppe, N. (1979): Jurchen and Mongolian. In: Schwartz, G. H. (ed.): Studies in Mongolia, Proceedings of the First North American Conference on Mongolian. Washington, pp. 30-37.

Pulleyblank, E. G. (ed.) (1991): Lexicon of Reconstructed Pronunciation in Early Middle Chinese, Late Middle Chinese and Early Mandarin. Vancouver.

Rachewiltz, I. de (1974): Some Remarks on the Khitan Clan Name Yeh-lü i-la. Papers on Far Eastern History 9, pp. 187-204.

Rachewiltz, I. de (2004): The Secret History of the Mongols. A Mongolian Epic Chronicle of the Thirteenth Century. Vols 1-2. Leiden - Boston.

Róna-Tas, A. (2014): Tibeto-Mongolica Revisited, with a New Introduction and Selected Papers on Tibetan Linguistics. Leiden-Boston.

Róna-Tas, A.-Berta, Á. (2011): West Old Turkic. Turkic Loanwords in Hungarian. Vols 1-2. Wiesbaden.

Rykin, P. (2014): Middle Mongol Affricates and the Reconstruction of (Pre-)Proto-Mongolic Affricates. $A O H$ Vol. 67 , pp. $425-452$.

Shimunek, A. (2011): Review of Kane's The Kitan Language and Scripts, 2009. AOH Vol. 64, pp. 101-107.

Shimunek, A. (2014): A New Decipherment and Linguistic Reconstruction of the Kitan-Chinese Bilingual Inscription of 1134 A.D. $A O H$ Vol. 67, pp. 97-118.

Smedt, A. de-Mostaert, A. (1933): La dialecte Monguor parlé par les Mongols du Kansou Occidentale, III partie: Dictionnaire monguor-français. Pei'ping.

Sun Bojun-Jing Yongshi-Li Yang (2010): Preliminary Proposal for Encoding Khitan Characters in 1UCS, ISO/IEC JTC/SC2/WG2.

Takeuchi, Yasunori (2015): Direction Terms in Khitan. Acta Linguistica Petropolitana: Transactions of the Institute for Linguistic Studies Vol. XI, Part 3, pp. 453-464.

Tokio Takata (1988): A Historical Study of the Chinese Language Based on Dunhuang Materials. The Hexi Dialect of the Ninth and Tenth Centuries. Tokyo (in Japanese).

Toyoda Gorō (1992): Guanyu Qidan xiaozi de fangwei he yixie shuci [On the directions and some numerals in the Khitan small script] In: Liu Fengzhu-Lu Xun-Hua Zugen (eds): Zhungguo minzushi yanjiu Vol. 4, Beijing.

Toyoda Gorō (1998): Qidan xiaozi suo baoliu xialai de zhonggu mengguyu zhi henji - yongfu, chunqiu, shuci [Traces of Middle Mongolian preserved in the Khitan Small Script: "tomb", "spring/autumn", numerals]. Ri-Zhong lianhe wenzi wenhua yantaohui fabiao lunwen ji. Kyoto, p. 151.

Tumurdej, G.-Cybenov, B. D. (2014): Kratkij dagursko-russkij slovar'. Ulan Udè.

Vovin, A. (2007): Once Again on the Tabgač Language. Mongolian Studies 29, pp. 191-206.

Vovin, A. (2011): A Modest Proposal on the Decipherment of the Khitan-Jurchen Bilingual Text of the 1134 (the Langjun) Inscription. In: Knüppel, M. - Tangerloo, van A. (eds): Life and Afterlife \& Apocalyptic Concepts in the Altaic World. Wiesbaden, pp. 123-130.

Vovin, A. (2013): Old Turkic Loanwords in the Khitan Language. In: Hatire Şirin User-Bülent Gül (eds): Yalım Kaya Bitigi. Osman Fikri Sertkaya Armağanı. Ankara, pp. 621-625.

Wittfogel, K.-Fêng Chia-shêng (1949): History of Chinese Society: Liao (907-1125). Philadelphia. 
Wu Yingzhe (2005): Qidan xiaozi 'xing' de yufa fanchou chutan (Preliminary research on the grammatical category of 'gender' in the Khitan Small Script). Neimenggu daxue xuebao (Zhexue Shehui Kexueban) Vol. 37, No. 3, pp. 25-28.

Wu Yingzhe-Janhunen, J. (2010): New Materials on the Khitan Small Script. A Critical Edition of Xiao Dilu and Yelü Xiangwen. Folkestone.

(to be continued) 